\title{
Ethnobotanical Survey of Medicinal Plants in Mwala Sub-County, Machakos County, Kenya
}

\author{
Caleb Mutwiwa ${ }^{1}$, Brian Rotich ${ }^{1,}$,, Matthaeus Kauti $^{2}$, Jafford Rithaa ${ }^{1}$ \\ ${ }^{1}$ Department of Environment and Resources Development, Chuka University, Chuka, Kenya \\ ${ }^{2}$ Department of Environmental Science \& Technology, School of Environment and Natural Resources Management, South Eastern Kenya \\ University (SEKU), Kitui, Kenya
}

Email address:

brotich@chuka.ac.ke(B. Rotich)

${ }^{*}$ Corresponding author

\section{To cite this article:}

Caleb Mutwiwa, Brian Rotich, Matthaeus Kauti, Jafford Rithaa. Ethnobotanical Survey of Medicinal Plants in Mwala Sub-County, Machakos County, Kenya. Journal of Diseases and Medicinal Plants. Vol. 4, No. 4, 2018, pp. 110-119. doi: 10.11648/j.jdmp.20180404.12

Received: September 25, 2018; Accepted: October 23, 2018; Published: November 13, 2018

\begin{abstract}
Studies on traditional use of medicinal plants can provide leads towards discovery of pharmaceutical drugs for treatment of both human and livestock diseases. This study sought to identify and document the use of medicinal plants by residents of Mwala Sub-county in Machakos County, Kenya. The research employed cross-sectional research design where simple random sampling was used to select the households to be sampled. A sample size of 61 households was used for the study and data collected by use of semi-structured questionnaires. Voucher specimens were collected, pressed, dried, mounted and identified at the Kenya Forestry Research Institute (KEFRI) Herbarium. Microsoft Excel Spreadsheet and Statistical Package for Social Sciences (SPSS) were used for data analysis and results presented in the form of tables and graphs. The study focused on identifying medicinal plants used, diseases treated, parts of the plant used, and methods of preparation and routes of administration. Research findings documented a total of 51 plants species from 31 families used to treat 38 different disease conditions in the study area. The commonly used plant species was Aloe secundiflora (11.1\%) while Malaria (19.8\%) was the most cited disease. The most used plant parts were the leaves $(52.8 \%)$ and bark (19.4\%). About $75.4 \%$ of the respondents acquired knowledge on medicinal plant use through apprenticeship from relatives. With the stocks of medicinal plants declining in the area, there is need for conservation, domestication and better management of key medicinal plants. Additionally, documentation of the indigenous knowledge is necessary to ensure intergenerational benefits from the herbal medicines.
\end{abstract}

Keywords: Bio Piracy, Indigenous Knowledge, Ethnobotany, Conservation

\section{Introduction}

Ethnobotany is the study of how people in a particular region or a given culture make use of their locally available native plants thus studies in ethnobotany and Traditional Ecological Knowledge (TEK) serves as a linkage between conservationists and local communities. Such studies shows how the locals interact with their environment thereby making a way for their participation in conservation [1] The World Health Organization [2] estimates that about $80 \%$ of the World's population in developing countries are still dependent on herbal medicine for their primary healthcare. About $95 \%$ of African drug needs comes from medicinal plants and as many as 5,000 plant species in Africa are medicinally significant [3]. Most African communities lack access to modern health facilities and services and they are vulnerable to health challenges experienced in their respective areas. They have therefore adopted the use local and indigenous knowledge in order to come up with remedies to such adversities [4]. Medicinal plants serve as a reservoir of curative elements used by a large population of African local communities in the cure and management of various diseases such as malaria, diabetes, respiratory infections, skin diseases, diarrhea, hypertension and mental disorders and many others [5]. In many cultures globally, the use of medicinal plants is common while most advanced pharmaceutical drugs have been derived from these plants 
[6]. Historical accounts and literature sources reveal that modern medicine has greatly benefited from traditional medicine particularly remedies derived from botanical medicinal plants [7]. Despite the dominance of traditional medicine in health provision globally there is, still very scanty documentation of the medicinal flora. There is an urgent need therefore to document these plants and the indigenous knowledge for future references [8]. Kenyans also have a hand in the use of medicinal plants. Over $70 \%$ of the population in Kenya relies on traditional medicine as their primary source of healthcare [9]. Traditional medicines play a major role in primary healthcare and upkeep of Kenyan rural communities and is preferred at the expense of modern drugs, since they are locally available, cheap, selfadministered and apparently effective [10].

Increased demand for medicinal products in the recent past has led to increased utilization, thus threatening survival of these plants in their natural habitats [11]. Unsustainable utilization of wild medicinal flora has been majorly as a result of increased commercialization of herbal products [12]. Unmonitored trade of medicinal plant resources, habitat loss, overexploitation, destructive harvesting techniques and habitat change are other primary threats to medicinal plant resources in developing nations [13]. Sindiga, [14], blames lifestyle changes inclined towards western culture to the loss of Ethnobotanical knowledge while others Cox [15] cites lack of interest by the young generation in traditional knowledge and ancient way of life, as the root causes of decreased use of medicinal plants. Conservation of medicinal plant species is therefore vital for local health as well as international drug development. Local knowledge an important tool in the conservation of natural resource and biodiversity $[11,16]$. Traditional knowledge on natural resources management however becomes more useful when integrated with the modern conservation approaches [17]. Ethno botanical research plays an imperative role in highlighting the highly utilized and endangered plants for conservation and sustainable utilization [18]. Clear management strategies are essential to avoid extinction of threatened medicinal plant species. Public awareness is equally important for sustainable utilization and conservation of wild plant stocks in regards to ensuring conservation of medicinal plants in Kenya [11, 19-20].

Mwala region, Machakos County of Kenya has a rich diversity of plants, some of which the locals rely on as remedies to both human and livestock ailments. In this remote region, several diseases are common and the people rely on the highly respected traditional practitioners who prescribe cures for many of the diseases using herbs, roots, charms and sometimes even rituals [21-22]. The people together with the local traditional healers have accumulated indigenous knowledge and practices on the use and processing of these plants for medicinal purpose. Local and traditional healers possess enormous information on traditional medicine [23]. However, these information has not been documented a factor which informed the study. The study therefore sought to document the different medicinal plant species in Mwala sub-county, diseases and ailments treated, threats to medicinal plants and the current conservation practices carried out.

\section{Description of Study Area and Methodology}

\subsection{Description of Study Area}

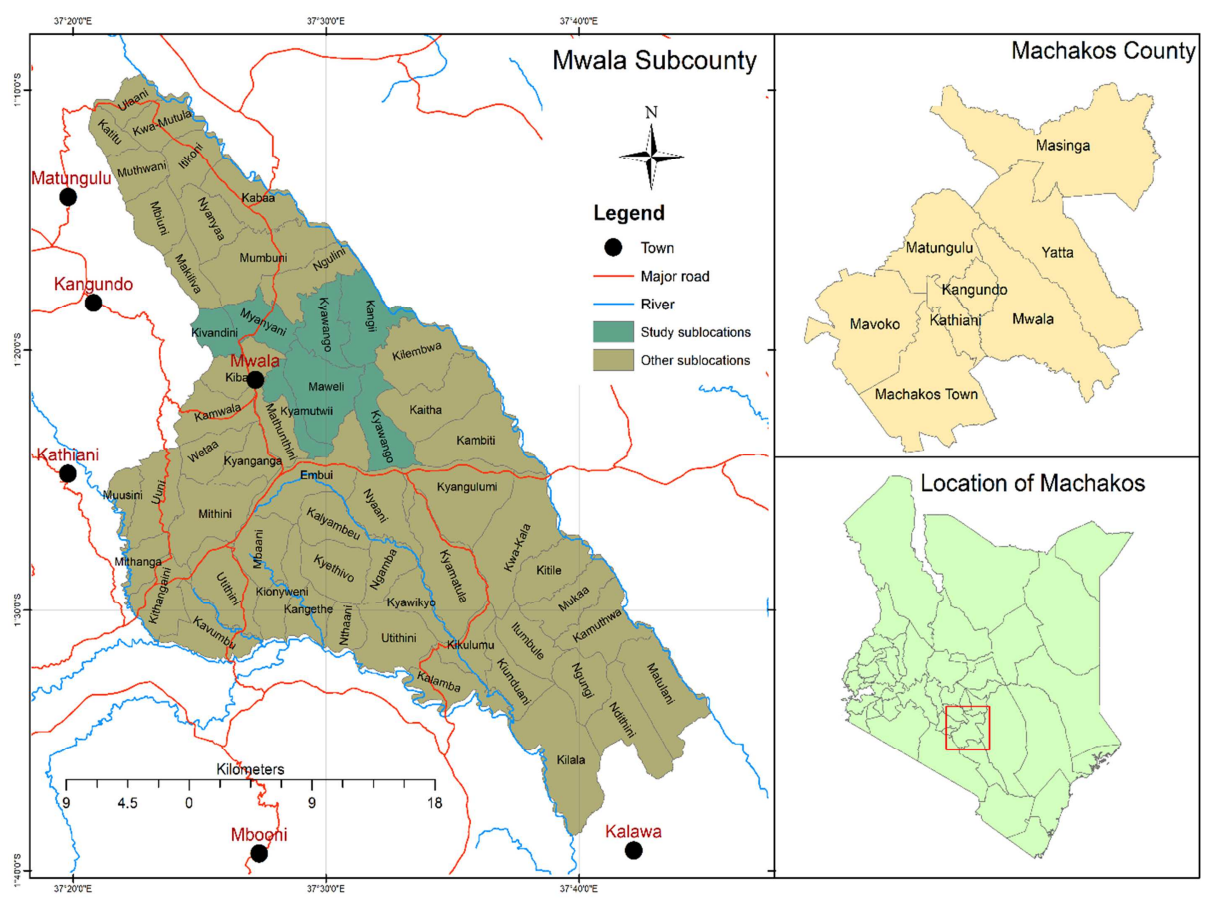

Figure 1. Map of the study area (Source: Author). 
This study was conducted in Mwala sub county, Machakos County, Kenya. The sub county covers an area of approximately $1,018 \mathrm{~km}^{2}$ and lies between $01^{\circ} 21^{\prime} 10.45^{\prime \prime} \mathrm{S}$, $37^{\circ} 27^{\prime} 10.35$ 'E (Figure 1). The area has ecologically distinct climate characterized by low and erratic bimodal rainfall with two distinct rainy seasons (short and long rains). The short rains which occur from October to December are more reliable and evenly distributed in this region [24]. The mean annual rainfall is about $596.7 \mathrm{~mm}$ and an altitude of $1186 \mathrm{~m}$ (A. S. L) and the mean annual temperatures range between $21.3^{\circ} \mathrm{C}$ to $22^{\circ} \mathrm{C}$ [25]. The sub county has a population of about 163,032 people. Dominant vegetation includes fruit trees including Mangifera indica, Citrus sinensis, Carica papaya, Acacia and Euphorbia tree species.

\subsection{Methodology}

Cross-sectional research design was used for this study. This design aims at investigating personal information related to attitude, belief and opinion of the target population. This study targeted 100 people which included key informants (herbalists), the general population (other people in the community with knowledge on medicinal plants) and herbal medicine vendors in the market.

The survey was conducted between December, 2017 and January, 2018 using structured questionnaires, Key Informant Interviews (KII), group discussions, demonstrations and guided field walks. Knowledgeable key informants were selected based on recommendations from the local people and the local community leaders. Study subjects were selected using random sampling technique six Sub-locations namely Maweli, Kyawango, Kivandini, Kyamutwii, Kangii and Myanyani. Selection was made from all households within the distance of 0 to $500 \mathrm{~m}$ along the Mwala-Kyawango road. From the sampled households, at least one member of the family was selected for the study regardless of age, education, sex and occupation as long as long as they were willing to participate in the study. Semi structured interviews were done for primary data collection. Interviews and group discussions were conducted in the local Kamba dialect and were complemented by field walks. Data collected revolved around socio economic characteristics of the respondents, local names of the plant species, medicinal uses, parts used, methods of preparation, and administration route were documented. Additional information on the conservation of the plants used as remedies to diseases was also noted down. Voucher specimens were collected, pressed, dried, mounted and identified in the Kenya Forestry Research Institute (KEFRI) herbarium and scientific names of collected species verified on Tropicos database [26]. The data collected was analyzed using SPSS and Microsoft excel 2013 and results presented in the form of tables, graphs and pie charts.

\section{Results and Discussions}

\subsection{Socio-Economic Characteristics of Respondents}

\subsubsection{Gender of the Respondents}

Majority of the respondents were males (54.1\%) whereas females formed $45.9 \%$ of the respondents. Previous studies indicate that gender-based knowledge is not homogeneous as it varies in various parts of the world and even within individual countries depending on the respective gender's interaction with natural resources. Some studies indicate that women are more knowledgeable about medicinal plants, other studies indicate that men know more while a number of studies also reveal no difference between the genders in terms of medicinal plant knowledge [27]

\subsubsection{Age of Respondents}

Age was considered in this study in order to understand the relationship between knowledge on medicinal plants and age and determine how age influences herbal knowledge. Majority of the key informants were above 50 years old. They were followed by respondents aged between 36-50 years $(27.9 \%), 19-35$ years old $(24.6 \%)$ and individuals who were less than 18 years old formed $14.8 \%$ of the respondents. These findings indicate that the elderly are more knowledgeable on medicinal plants than the young due to their lengthy interaction with the plant resources in their environment. This in itself poses a threat to indigenous knowledge continuity on herbal medicine from one generation to another if appropriate measures are not taken to ensure the young are trained on the same.

\subsubsection{Level of Education}

In order to fully understand the relationship between education and knowledge on medicinal plant processing, respondents were requested to indicate their levels of education. Majority $47.5 \%$ had primary school education while $41.0 \%$ had secondary school education. Only $4.9 \%$ of them had tertiary education. About $6.6 \%$ of the respondents had no formal education. Mwala sub-county residents with formal education were more likely to be influenced by the western culture to rely on modern medicine than plant medicine. Educated people tend to be more acculturated due to influence of modern education and lifestyle, they seek conventional medical treatment thus have less time with traditions compared to the less educated [28].

\subsubsection{Household Size}

Household size is one of the factors that can influence the reliance on traditional medicine and the rate of harvesting for treatment. Majority of the households (55.7\%) had 4-6 members, followed by $2-3$ members (19.7\%). About $16.4 \%$ of the households had 7-9 members while $8.2 \%$ had only one family member. In most rural setups, households with many household members are more likely to rely on medicinal plants due to expenses associated with purchasing modern medicine 
and seeking modern health services for all members.

\subsubsection{Occupation of Respondents}

The respondents comprised farmers (45.9\%). Students $19.7 \%$, business persons formed $8.2 \%$ of respondents and $6.6 \%$ were casual laborers. About $3.3 \%$ of the respondents were herbalists, $1.6 \%$ clergy, $1.6 \%$ Mechanics, $4.9 \%$ housewives, $3.2 \%$ civil servants, $3.3 \%$ craftsmen, and $1.6 \%$ Drivers. This means that most of the respondents interacted with medicinal plants while farming thus might have knowledge on the important medicinal plants.

\subsection{Medicinal Plant Species in Mwala Sub-County}

Medicinal plant species in the study area were documented to provide a checklist for future reference. The Table below gives a summary of all the medicinal plant species identified during the study.

Table 1. Medicinal plants, part used, diseases treated and mode of administration

\begin{tabular}{|c|c|c|c|c|c|c|}
\hline S.NO & Botanical Name & Local Name & Family & Part Used & Therapeutic uses & Mode of administration \\
\hline 1 & Acacia brevispica & Mukuswi & Mimosoideae & Leaf & Giddiness and Cough & $\begin{array}{l}\text { Crushed and Infusion Orally } \\
\text { administered }\end{array}$ \\
\hline 2 & Acacia mellifera & Muthiia & Mimosoideae & Bark & Cough & $\begin{array}{l}\text { Crushed and Infused Orally } \\
\text { taken }\end{array}$ \\
\hline 3 & Acacia nilotica & Musemei & Mimosoideae & Bark & Cough & $\begin{array}{l}\text { Crushed, boiled and Infused } \\
\text { orally }\end{array}$ \\
\hline 4 & Acacia tortilis & Kilaa & Mimosoideae & Bark & $\begin{array}{l}\text { Swollen abdomen and } \\
\text { cough }\end{array}$ & $\begin{array}{l}\text { Chewed or soaked and orally } \\
\text { administered }\end{array}$ \\
\hline 5 & Erythrocephalu marginatum & Kakunini & Compositae & Whole & Malaria & $\begin{array}{l}\text { Boiled and Decoction } \\
\text { Orally administered }\end{array}$ \\
\hline 6 & Agave sisalana & Ikonge & Asparagaceae & Leaf & Cuts and Wounds & Sap squeezed and applied \\
\hline 7 & Aloe secundiflora & Kiluma & Euphorbiaceae & Leaf & Malaria, Fatigue & $\begin{array}{l}\text { Decoction or infusion Orally } \\
\text { taken }\end{array}$ \\
\hline 8 & Altenanthera pungens & Kakwasi & Amaranthaceae & Roots & Toothache & $\begin{array}{l}\text { Pounded and infusion Orally } \\
\text { taken }\end{array}$ \\
\hline 9 & Aspilia pluriseta & Muti & Compositae & Leaf & Wounds and Snake bites & Sap squeezed and applied \\
\hline 10 & Azadirachta indica & Mualuvaini & Meliaceae & Bark, Leaves & Malaria and Joint pains & $\begin{array}{l}\text { Pounded or boiled and } \\
\text { infusion orally taken }\end{array}$ \\
\hline 11 & Balanites aegyptiaca & Kilului & Balanitaceae & Fruit & Headache & Chewed to remove pulp \\
\hline 12 & Barleria ventricosa & Kailawimbu & Acanthaceae & Whole & Rheumatism & $\begin{array}{l}\text { Crushed and Infusion Orally } \\
\text { administered }\end{array}$ \\
\hline 13 & Bidens pilosa & Munzee & Asteraceae & Leaf, seeds & $\begin{array}{l}\text { Ear complications and } \\
\text { Toothache }\end{array}$ & $\begin{array}{l}\text { Pounded and infusion Orally } \\
\text { taken }\end{array}$ \\
\hline 14 & Carica papaya & Muvavai & Caricaceae & $\begin{array}{l}\text { Stem, Fruit and } \\
\text { Leaves }\end{array}$ & $\begin{array}{l}\text { Toothache, Ulcers and } \\
\text { Malaria }\end{array}$ & $\begin{array}{l}\text { Sap applied, leaf boiled, Fruit } \\
\text { eaten }\end{array}$ \\
\hline 15 & Carissa spinarum & Mukawa & Apocynaceae & Roots & Joint Pains & $\begin{array}{l}\text { Boiled and Infusion Orally } \\
\text { taken }\end{array}$ \\
\hline 16 & Catha edulis & Miraa & Celastraceae & Leaves & Fatigue & Chewed \\
\hline 17 & Citrus limon & Kitimo & Rutaceae & Fruit & Skin Rashes and Cough & Fruit eaten \\
\hline 18 & Croton megalocarpus & Kithulu & Euphorbiaceae & $\begin{array}{l}\text { Bark, Leaves and } \\
\text { Seeds }\end{array}$ & $\begin{array}{l}\text { Kidney failure, lungs and } \\
\text { Cough }\end{array}$ & $\begin{array}{l}\text { Concoction, Crushed and } \\
\text { Infusion orally administered }\end{array}$ \\
\hline 19 & Cynodon dactylon & Ikoka & Poaceae & Leaves & Stomachache & Chewed \\
\hline 21 & Grewia similis & Mutuva & Tiliaceae & Bark & Constipation & Chewed \\
\hline 22 & Jatropha curcas & $\begin{array}{l}\text { Kitanyuka- } \\
\text { mwene }\end{array}$ & Euphorbiaceae & Roots & Mouth Blisters & Chewed \\
\hline 23 & Kleinia squarrosa & $\begin{array}{l}\text { King'endya } \\
\text { Nthenge }\end{array}$ & Asteraceae & $\begin{array}{l}\text { Bark, Leaves and } \\
\text { Stem }\end{array}$ & $\begin{array}{l}\text { Cholera, Thrombosis and } \\
\text { Malaria }\end{array}$ & $\begin{array}{l}\text { Concoction, Crushed and } \\
\text { Infusion orally taken }\end{array}$ \\
\hline 24 & Lannea schweinfurthii & Kyuasi & Anacardiaceae & Bark & Pneumonia & $\begin{array}{l}\text { Boiled and infusion Orally } \\
\text { administered }\end{array}$ \\
\hline 25 & Lantana camara & Mukiti & Verbenaceae & Leaves & Wounds & $\begin{array}{l}\text { Crushed and Infusion Taken } \\
\text { orally }\end{array}$ \\
\hline 26 & Launaea cornuta & Uthunga & Asteraceae & Leaves & Chest pain & $\begin{array}{l}\text { Crushed and Infusion Taken } \\
\text { orally }\end{array}$ \\
\hline 27 & Mangifera indica & Kiembe & Anacardiaceae & $\begin{array}{l}\text { Bark, Leaves and } \\
\text { Roots }\end{array}$ & $\begin{array}{l}\text { Toothache, Ringworms, } \\
\text { Diarrhea }\end{array}$ & $\begin{array}{l}\text { Boiled or Roasted and } \\
\text { Grinded or pounded and } \\
\text { infusion orally administered }\end{array}$ \\
\hline 28 & Moringa oleifera & Muringa & Moringaceae & $\begin{array}{l}\text { Flower, Leaf, } \\
\text { Seeds and Roots }\end{array}$ & $\begin{array}{l}\text { Malaria, Hypertension, } \\
\text { toothache, Ulcers, Teeth- } \\
\text { whitening }\end{array}$ & $\begin{array}{l}\text { Chewed, Boiled and Infusion } \\
\text { taken orally. }\end{array}$ \\
\hline 29 & Morus alba & Kitae & Moraceae & Fruit & Blood Recharge & Chewed \\
\hline 30 & Ocimum kilimandscharicum & Mutaa & Labiatae & Leaves and seeds & $\begin{array}{l}\text { Constipation, Cough and } \\
\text { Eye problems }\end{array}$ & $\begin{array}{l}\text { Crushed and Infusion Orally } \\
\text { taken or rubbed in the eye }\end{array}$ \\
\hline 31 & Ormocarpum trichocarpum & Muthingii & Fabaceae & Leaves & Ulcers & Crushed and infusion Orally \\
\hline
\end{tabular}




\begin{tabular}{|c|c|c|c|c|c|c|}
\hline S.NO & Botanical Name & Local Name & Family & Part Used & Therapeutic uses & Mode of administration \\
\hline 32 & Oxygonum sinuatum & Musong'e & Polygonaceae & Leaves & Toothache & $\begin{array}{l}\text { administered. } \\
\text { Chewed for sap. }\end{array}$ \\
\hline 33 & Plectranthus barbatus & Muvou & Lamiaceae & Leaves & $\begin{array}{l}\text { Stomachache and Joint } \\
\text { Pains }\end{array}$ & $\begin{array}{l}\text { Chewed or Crushed and } \\
\text { Infusion taken orally. }\end{array}$ \\
\hline 34 & Psidium guajava & Kivela & Myrtaceae & Leaves & Diarrhea and Stomachache & $\begin{array}{l}\text { Crushed and infusion Orally } \\
\text { administered }\end{array}$ \\
\hline 35 & Searsia natalensis & Mutheu & Anacardiaceae & Leaves & Diarrhea and Stomachache & $\begin{array}{l}\text { Crushed, Soaked And infusion } \\
\text { taken orally. }\end{array}$ \\
\hline 36 & Ricinus communis & Kyaiki & Euphorbiaceae & Seeds & Constipation & Chewed. \\
\hline 37 & Senna siamea & Mukengeta & Caesalpiniodeae & Leaves, Stem & Malaria and Ulcers & $\begin{array}{l}\text { Roasted or boiled and } \\
\text { Infusion orally taken. }\end{array}$ \\
\hline 38 & Senna spectabilis & Mukengeta 2 & Caesalpiniodeae & Leaves & Cramping & Concoction. \\
\hline 39 & Solanum incanum & Mukondu & Solanaceae & Leaves and Roots & Stomachache & $\begin{array}{l}\text { Chewed or Crushed And } \\
\text { Infusion orally taken. }\end{array}$ \\
\hline 40 & Solanum americanum & Managu & Solanaceae & Leaves & Tonsils & Chewed or cooked. \\
\hline 41 & Steganotaenia araliacea & Kivuavui & Apiaceae & Bark & Oedema & $\begin{array}{l}\text { Boiled and Infusion Orally } \\
\text { administered. }\end{array}$ \\
\hline 42 & Strychnos spinosa & Muteta & Loganiaceae & Roots & Cold flu & $\begin{array}{l}\text { Boiled and Infusion Orally } \\
\text { taken. }\end{array}$ \\
\hline 43 & Euphorbia bicompacta & Kyatha & Euphorbiaceae & $\begin{array}{l}\text { Bark, Leaves and } \\
\text { Branches }\end{array}$ & $\begin{array}{l}\text { Tonsils and Ear } \\
\text { complications }\end{array}$ & Sap squeezed and applied \\
\hline 44 & Synadenium spp & Kilembwa & Euphorbiaceae & Bark and Stem & $\begin{array}{l}\text { Ulcers, Swollen abdomen } \\
\text { and Toothache }\end{array}$ & $\begin{array}{l}\text { Roasted, grinded and powder } \\
\text { infused and orally taken. }\end{array}$ \\
\hline 45 & Tamarindus indica & Kithumula & Caesalpiniodeae & Fruit & Arthritis & $\begin{array}{l}\text { Soaked and Infusion Taken } \\
\text { orally. }\end{array}$ \\
\hline 46 & Terminalia brownii & Muuku & Combretaceae & Bark and Leaves & Yellow Fever, ulcers & $\begin{array}{l}\text { Crushed, Boiled and Infusion } \\
\text { taken orally. }\end{array}$ \\
\hline 47 & Cascabela theretia & Ilaa & Apocynaceae & Fruit and Leaves & $\begin{array}{l}\text { Lungs in Livestock and } \\
\text { Wounds on Humans }\end{array}$ & $\begin{array}{l}\text { Infusion taken orally or sap } \\
\text { applied on wounds. }\end{array}$ \\
\hline 48 & Tithonia diversifolia & Ilaa 2 & Asteraceae & Whole plant & Stomachache & $\begin{array}{l}\text { Crushed and infusion Orally } \\
\text { administered. }\end{array}$ \\
\hline 49 & Baccharoides lasiapus & Muvatha & Compositae & Leaves & Stomachache and Lungs & $\begin{array}{l}\text { Crushed and Infusion Taken } \\
\text { orally. }\end{array}$ \\
\hline 50 & Ximenia americana & Mutula & Olacaceae & Roots & Joint Pains & $\begin{array}{l}\text { Boiled and Infusion Orally } \\
\text { taken. }\end{array}$ \\
\hline 51 & Zanthocylum chalybeum & Mukenea & Rutaceae & Bark and Leaves & $\begin{array}{l}\text { Malaria, Ulcers and } \\
\text { Cough }\end{array}$ & $\begin{array}{l}\text { Boiled and Infusion Orally } \\
\text { administered. }\end{array}$ \\
\hline
\end{tabular}

A total of 51 plant species distributed across 31 families were recorded in the study area together with 5 vouchers. The top six medicinal plant species mentioned by respondents included Aloe secundiflora (locally known as Kiluma) which was the most popular, having been mentioned 28 times by the respondents. Other commonly used plant species were Moringaoleifera mentioned 22 times, Terminalia brownie 19 times, Azadirachtaindica 18 times, Solanum incanum 17 times, Psidium guajava 11 times among others. Conservation efforts should therefore be geared towards the above mentioned species as they are important elements in the treatment of various diseases in the study area. Of the 51 plant species, $91.67 \%$ were used to treat human diseases while only $7.94 \%$ are used treat livestock diseases. The remaining $(0.39 \%)$ were used to treat both human and livestock ailments.

\subsection{Diseases Treated and Plant Parts Used}

A total of 38 disease conditions were mentioned. Malaria (19.84\%) was the most common disease mentioned. This was followed by Stomachache (13.49\%), coughing (9.52\%), wounds and Lung complication (5.56\%) among others. The diseases were further grouped into different categories and the number and percentage of the total species used for treatment summarized as shown in table 2 below

Table 2. Ailment categories treated by different plants as per International Statistical Classification of Diseases and Related Health Problems 10th Revision (ICD-10)-WHO Version for; 2016.

\begin{tabular}{|c|c|c|c|c|}
\hline $\begin{array}{l}\text { ICD-10)-WHO } \\
\text { Version for; } 2016 \\
\end{array}$ & Ailment category & Specific condition & $\begin{array}{l}\text { No. of species } \\
\text { used }(\mathrm{N}=51) \\
\end{array}$ & $\begin{array}{l}\text { \% of total } \\
\text { species }\end{array}$ \\
\hline $\mathrm{XI}$ & Digestive disorders & $\begin{array}{l}\text { Diarrhea, stomachache, } \\
\text { constipation, ulcers, cholera, } \\
\text { blotting }\end{array}$ & 19 & 37.3 \\
\hline $\mathrm{X}$ & Diseases of the respiratory system & $\begin{array}{l}\text { Cough, chest pains, } \\
\text { pneumonia, lungs, cold }\end{array}$ & 14 & 27.5 \\
\hline XII & Diseases of the skin and subcutaneous tissue & $\begin{array}{l}\text { Wounds, skin rashes, } \\
\text { smallpox, ringworms }\end{array}$ & 8 & 15.7 \\
\hline III & Diseases of the blood and blood-forming organs and certain & Blood cleansing, thrombosis & 2 & 4 \\
\hline
\end{tabular}




\begin{tabular}{|c|c|c|c|c|}
\hline $\begin{array}{l}\text { (ICD-10)-WHO } \\
\text { Version for; } 2016\end{array}$ & Ailment category & Specific condition & $\begin{array}{l}\text { No. of species } \\
\text { used }(\mathrm{N}=51)\end{array}$ & $\begin{array}{l}\% \text { of total } \\
\text { species }\end{array}$ \\
\hline & disorders involving the immune mechanism & & & \\
\hline XIV & Diseases of the genitourinary system & Cramping, Kidney failure & 2 & 4 \\
\hline XII & Diseases of the musculoskeletal system and connective tissue & Joint pains, rheumatism & 6 & 12 \\
\hline I & Certain infectious and parasitic diseases & $\begin{array}{l}\text { Malaria, yellow fever, mouth } \\
\text { blisters }\end{array}$ & 10 & 19.6 \\
\hline IX & Diseases of the circulatory system & hypertension & 1 & 2 \\
\hline XVIII & $\begin{array}{l}\text { Headache and fatigue Symptoms, signs and abnormal clinical } \\
\text { and laboratory findings, not elsewhere classified }\end{array}$ & Migraines, headaches, fatigue & 3 & 5.9 \\
\hline XIX & $\begin{array}{l}\text { Injury, poisoning and certain other consequences of external } \\
\text { causes }\end{array}$ & Snake bites & 1 & 2 \\
\hline
\end{tabular}

Different plant parts were used for the treatment of different diseases and ailments. From all the citations made, the leaf $(52.78 \%)$ was the most mentioned part, bark $19.44 \%$, roots $10.32 \%$, the whole plant $(2.38 \%)$, seeds $(4.76 \%)$, the stem $(6.35 \%)$, fruit $(3.17 \%)$, Branches and flowers $(0.40 \%)$ each as shown in figure 2 below

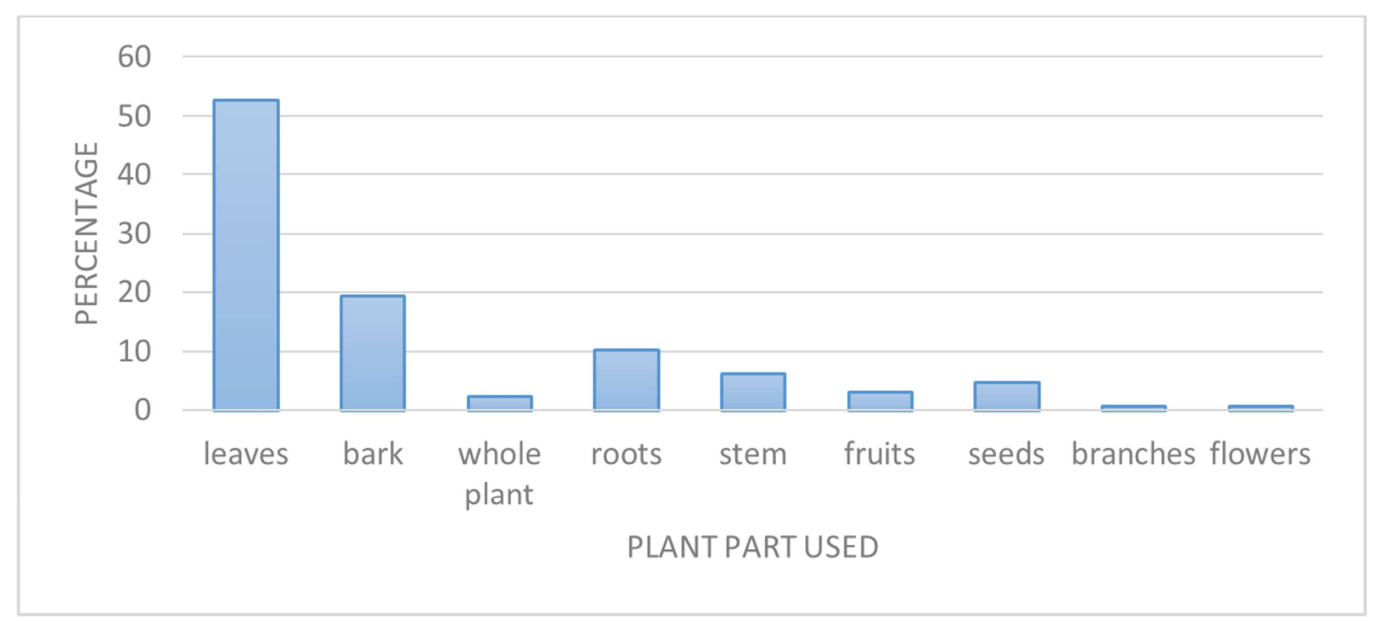

Figure 2. Plant parts used.

An estimate of the threat to medicinal plants can be made from the type of plant and the part used [29] Most remedy processing activities in the study area used the leafy parts of plants, and this could have an effect on photosynthesis process of plants. Studies conducted in Kenya, Ethiopia and in other parts of the world show that leaves are the most used plant parts for herbal medicine more than the other parts of a plant. This could pose a threat on plant species if unsustainably harvested. However according to Kalayu [18] harvesting of leaves compared roots in the study area has less negative influence on the survival and sustainability of medicinal plants in comparison to uprooting the whole plant or use of the roots. Bark harvesting also poses a threat to the plants since removal of the bark disrupts the translocation and exchange of food, water and nutrients between roots and leaves.

\subsection{Mode of Preparation and Administration}

The study results indicated that the methods of preparation employed primarily for single plant parts used were Decoction $(22.22 \%)$, followed by Chewing $(21.83 \%)$ and Pounding $(9.13 \%)$ then infusing in hot or cold water to make hot and cold infusions respectively. Crushing (6.75\%) and Pounding (7.54\%) were other common modes of preparation. A decoction is prepared by boiling plant parts of single plant species in water. Crushing and Pounding were done using two stones. One flat shaped and the other oval or spherical shaped to fit into the hands. The solvent was water.

Pounding also involved the use of a traditional mortar and pestle. Roasting took $2.38 \%$ and the most roasted species was Synadenium species. Once the plant was roasted, the resulting powder would be ground and applied topically on the affected part or infused in water mainly to treat a swollen abdomen. These remedies were prepared when required, thus most interviewees and the herbalists did not preserve the medicines.7.94\% of the modes of remedy preparation involved processing mainly as mixtures in the form of concoctions. To prepare a concoction, plant parts are obtained from more than one plant species and boiled together in water. Majority, $82.94 \%$ of the respondents said that they use oral method to administer the prepared medicine. Only $17.06 \%$ of them applied the prepared medicine through the topical application.

\subsection{Reasons for Using Medicinal Plants}

The researcher sought to find out the reasons behind the continued use and preference of herbal medicine even with the availability of conventional medicine.

Majority $(34.4 \%)$ of the respondents indicated that they prefer medicinal plants for treatment of diseases due to their 
efficiency. Other reasons mentioned included availability $(27.9 \%)$, lack of side effects $(24.6 \%)$, cheapness $(8.2 \%)$ and long distance to health centers $(4.9 \%)$ as shown in figure 3 below.

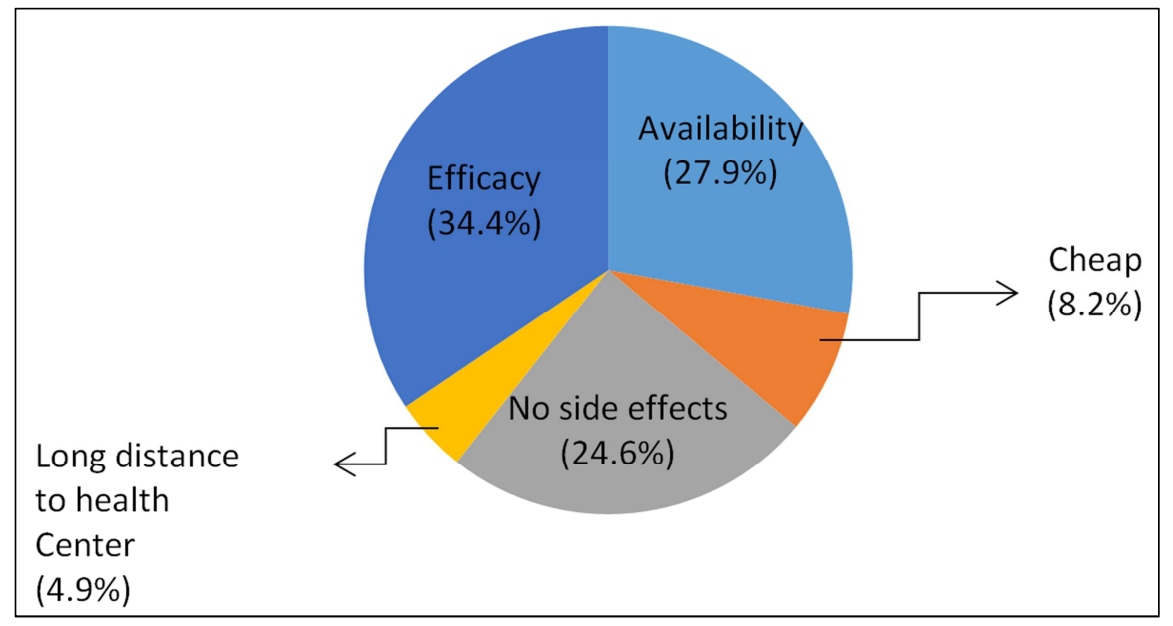

Figure 3. Reasons for use of medicinal plants.

A report by the World Health Organization of the United Nation [2] singles out the affordability and unavailability of modern health facilities as some of the reasons for preference of medicinal plants by rural households. Kaingu et al. [30] and Nagata et al [31], further cite the long distance to health centers, unreliable transport services and lack of financial resources are some of the reasons that make herbal medicine to be more reliable to people.

\subsection{Conservation Practices}

Table 3 below shows the current conservation efforts of medicinal plants carried out in the study area by the residents.

Table 3. Medicinal plants conservation measures.

\begin{tabular}{lll}
\hline Conservation measure & $\begin{array}{l}\text { Frequency } \\
(\mathbf{N = 6 1 )}\end{array}$ & $\begin{array}{l}\text { Percentage } \\
\mathbf{( \% )}\end{array}$ \\
\hline Domestication & 34 & 55.7 \\
Trainings on conservation & 11 & 18.0 \\
Protection by conservation groups & 6 & 9.8 \\
Others & 3 & 4.9 \\
None & 3 & 4.9 \\
Efforts by administrative officers & 3 & 4.9 \\
Community scouts & 1 & 1.6 \\
Total & 61 & 100 \\
\hline
\end{tabular}

Majority $55.7 \%$ of the respondents indicated that domestication of medicinal plants is a common practice of conserve plants in the area. $18 \%$ indicated that there are trainings carried out in the area to conserve and protect medicinal plants while 9.8\% indicated that there are groups and Community Based Organizations (CBOs) that assist in conserving medicinal plants. $4.9 \%$ of the respondents indicated that the Local area chief takes efforts to encourage people to conserve medicinal plants, $4.9 \%$ others indicated that other conservation measures such as planting trees are undertaken while $4.9 \%$ others indicated that there are no measures that are being taken to conserve medicinal plants in the area. $1.6 \%$ indicated that scouts from the local institutions at a particular time participate in medicinal plant conservation.

\subsection{Respondents' Perception on the Threats to Medicinal Plants}

Respondents were asked to list various threats to medicinal plants in Mwala. Table 4 below indicates perceived threats by the respondents to the medicinal plants.

Table 4. Threats to medicinal plants.

\begin{tabular}{lll}
\hline Threat & Frequency $\mathbf{( N = 6 1 )}$ & Percentage (\%) \\
\hline Overgrazing & 15 & 24.6 \\
Climate change & 15 & 24.6 \\
Charcoal burning & 9 & 14.8 \\
Clearing for cultivation & 7 & 11.5 \\
Overharvesting & 6 & 9.8 \\
Lack of awareness & 5 & 8.2 \\
Others & 4 & 6.6 \\
Total & 61 & 100 \\
\hline
\end{tabular}

The respondents indicated that medicinal plants in the area are perceived to face a number of threats. Majority (24.6\%) indicated that Overgrazing and climate change were the main threats to conservation of medicinal plants each. Charcoal burning (14.8\%), Overharvesting (9.8\%) and clearing for cultivation (11.5\%). A section of the respondents $(6.6 \%)$ indicated that the threats to medicinal plants in the study area included cultural changes, habitat loss, urbanization and lack of potential candidates for training as most youth were not interested. A study by Maunguja [32] also listed Charcoal production, Climate change and drought and deforestation as some of the threats facing medicinal plants in Arabuko Sokoke Forest, Kilifi Kenya. Grazing management practices and proper stocking should be encouraged in the study area to reduce overgrazing. Cultivation of fast growing species for charcoal production and the promotion of alternative fuel energy sources would help reduce the pressure on medicinal plants. 


\subsection{Methods of Herbal Knowledge Acquisition}

Respondents indicated several ways in which they gained herbal knowledge as summarized in figure 4 below. Majority $(75.4 \%)$ of them indicated they gained knowledge through apprenticeship from their relatives. Other methods of knowledge acquisition included induction from mobile practitioners $(14.8 \%)$, Formal training $(3.3 \%)$ and own observation $(6.6 \%)$.

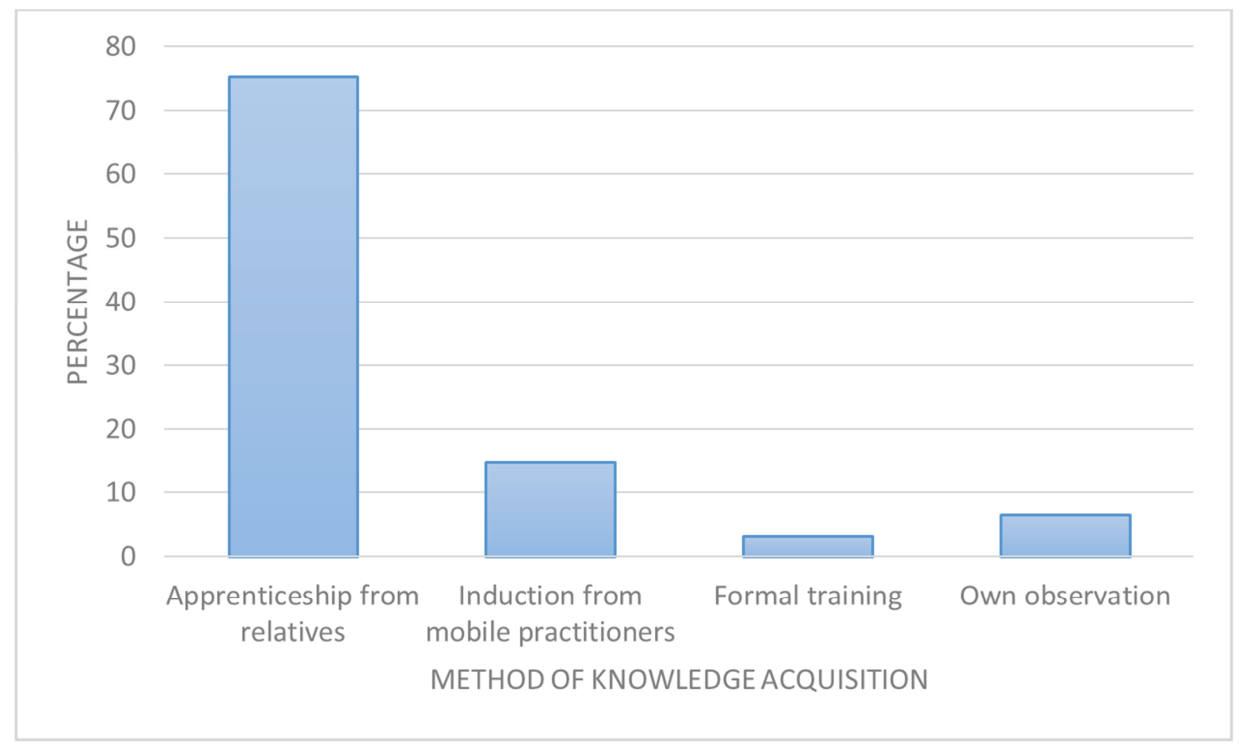

Figure 4. Method of herbal knowledge acquisition.

Apprenticeship from relatives therefore was the most effective way of passing herbal information. These findings match that by Kisangau et al. [33] conducted in Kitui County, Kenya, where he found out that majority of the respondents $(89 \%)$ gained herbal knowledge through apprenticeship from experienced family relatives. Knowledge of traditional herbal medicine is passed from one generation to another by oral means, through training by knowledgeable individuals or through inheritance. Herbal knowledge is however susceptible to loss because due to a number of challenges facing apprenticeship including lack of interest by the young [20] and in some cases the old people do not have apprentices or prefer secrecy when collecting herbal products [34-35]. Ethnobotanical pharmacopoeia is importantly used in intervention of disease and need arises for documentation and preservation of tradition medicinal knowledge to boost the discovery of new drugs [36-37].

\section{Conclusion}

From the study, it is evident that there exists a diversity of medicinal plants in Mwala and the people in the study area have immense knowledge on use of plants for medicinal purposes hence patenting and documenting of these species is therefore necessary for safe custody. Relevant education institutions and government agencies within the area should therefore work towards documenting the indigenous knowledge to ensure the knowledge does not get lost or get buried with the elderly who act as custodians to the knowledge. Traditional healers should also be well trained on conservation to protect the disappearing species and knowledge base. A high proportion of households were found to use medicinal plants for the treatment of various diseases with malaria being the most cited disease. The most used parts were leaves, bark and roots. Widespread utility of roots and bark accompanied by anthropogenic factors such as overgrazing, charcoal burning, and clearing forests for cultivation, deforestation and climate change contributed a considerable proportion of threat to medicinal plants in the area. Conservation and sustainable use of the valuable plant species is essential.

In order to minimize the drawbacks of traditional medicine and to upgrade the health services in Mwala Sub-county, local medicinal practitioners should be given technical support through the department of culture and social services through licensing for accountability and value addition support in processing, packaging and marketing of the herbal medicine.

\section{Acknowledgements}

We are thankful to residents of Mwala for their input during data collection. Much gratitude to officials from the Kenya Forestry Research Institute (KEFRI) for their assistance in specimen identification.

\section{References}

[1] Hamilton, A. (2002) Curriculum development in applied ethnobotany. Proceedings of the workshop on curriculum development in applied ethnobotany, Nathiagali, pp 91-9.

[2] World Health Organization (2002). Traditional medicine growing needs and potential. WHO Policy Perspectives Med., 2: $1-6$. Retrieved on $05 / 03 / 2018$ from http://apps.who.int/medicinedocs/es/d/Js2293e/. 
[3] Taylor, J. L. S., Elgorashi, E. E., Maes, A., Van Gorp, U., De Kimpe, N., Van Staden, J., Verschaeve, L., (2003). Investigating the safety of plants used in South African traditional medicine: testing for genotoxicity in the micronucleus and alkaline comet assays. Environmental and Molecular Mutagenesis 42, 144-154.

[4] Wanzala, W., Zessin, K. H., Kyule, N. M., Baumann, M. P. O., E Mathias, E. \& Hassanali, A. (2005). Ethnoveterinary medicine: a critical review of its evolution, perception, understanding and the way forward. Livestock Research for Rural Development, 17 (11):119.

[5] Okigbo, R. N., Anuagasi C. L. \& Amadi J. E. (2009). Advances in selected medicinal and aromatic plants indigenous to Africa. Journal of Medicinal Plants Research 3: 086-095.

[6] National Institute of Health (NIH). 1994. Office of alternative medicine - Fact sheet No.7- June 1994. www.aegis.com/pubs/cdc_fact_sheets/1994/cdc 94033.html.

[7] Abebe, D. (1996). The development of drug research. Ethiopian Health Natural. Res. Institute News Letter., 1: 5-6.

[8] Amuka O, Mulei JM, Gatwiri BP. A Brief Ethnbotanical Survey of Some Medicinal Plants Used by the Kanjoo Community in Meru County, Kenya. Adv Biotech \& Micro. 2017; 5 (1): 555654. DOI: 10.19080/AIBM.2017.05.555654.

[9] Kisangau, D. P. \& Herrmann, T. M. (2007). Utilization and conservation of medicinal plants used for primary health care in Makueni district, Kenya, International Journal of Biodiversity Science and Management, 3:3, 184-192.

[10] Wandago, B, \& Chemonges, M. (2006). The impact of governance and regulatory frameworks in sustainable use of dryland resources; case study of Mukogondo and Mt. Kenya ecosystems, Kenya. Proceedings of the regional workshop on sustainable use of drylands biodiversity (RPSUD) held at Hotel Impala, Arusha Tanzania $7^{\text {th }}-9^{\text {th }}$ June 2006 3-8.

[11] Jeruto, P., Lukhoba, C., Ouma, G., Otieno, D., \& Mutai, C. (2008). An Ethnobotanical study of medicinal plants used by the Nandi people in Kenya. Journal of Ethno pharmacology, $116(2), 370-376$

[12] Kala, C. P. (2005). Indigenous uses, population density, and conservation of threatened medicinal plants in protected areas of the Indian Himalayas. Conservation Biology, 19 (2), 368378 .

[13] Dharani, N., \& Yenesew, A. (2010). Medicinal Plants of East Africa: An illustrated guide. Najma Dharani in association with Drongo Editing and Publishing, Sterling publishers Pvt. Ltd. New Delhi, India.

[14] Sindiga, I. (1995). African ethno medicine and other medical systems. Traditional medicine in Africa, 9966-46.

[15] Cox, P. A. (2000). Will tribal knowledge survive the millennium? Science, 287 (5450), 44-45.

[16] Wekesa, C., Ndalilo, L., Ongugo, P., Leley, N., and Swiderska, K. (2015). Traditional knowledge based innovations for adaptation and resilience to climate change: the case of coastal Kenya.

[17] Berkes, F., and Turner, N. J. (2006). Knowledge, learning and the evolution of conservation practice for social-ecological system resilience. Human Ecology, 34 (4), 479-494.

[18] Kalayu, M, Gebru., T. \& Teklemichael, T. (2013). Ethnobotanical study of medicinal plants used by Indigenous people of Gemad District, Northern Ethiopia. www.plantsjournal.com.

[19] Bussmann, R. W. (2006). Ethnobotany of the Samburu of Mt. Nyiru, South Turkana, Kenya. Journal of Ethno biology and Ethno medicine, 2 (1), 1.

[20] Kigen, G. K., Ronoh, H. K., Kipkore, W. K., \& Rotich, J. K. (2013). Current trends of traditional herbal medicine practice in Kenya: a review. African Journal of Pharmacology and Therapeutics, 2 (1), 32-37.

[21] Bisiker, L., Jenkins, R., Kanui, K. \& Musembi, C. (2011). Pain and its management in a traditional rural community in the Eastern Province of Kenya. Journal of Alternative Medicine Research 2, 51-60.

[22] Wagate, C., Mbaria, J., Gakuya, D., Nanyigi, M., Kareru, P., Njuguna, A., Gitahi, N., Macharia, J. \& Njonge, F., (2009). Screening of some Kenyan medicinal plants for antibacterial activity. Memórias do Instituto Oswaldo Cruz 103, 650-652.

[23] Gebremedhin, R. E., Tewedros, A. D., Lidet, B. T. and Daniel, F. B. (2015). Ethnoveterinary medicinal plants: Preparation and application methods by traditional healers in selected districts of southern Ethiopia; Vet World. 2015 May; 8 (5):674-84.

[24] Biamah, E. K. (2005). Coping with drought: Options for soil and water management in semiarid Kenya. Tropical Resource Management Papers, No. 58. Wageningen University and Research Centre (Wageningen UR).

[25] Karuma A. N., Charles, K. K., Gachene, Balthazar M. Msanya, Peter., W. Mtakwa, Nyambilila Amuri \& Patrick T. G. (2015). Soil Morphology, Physico-Chemical Properties and Classification of Typical Soils of Mwala District, Kenya. International Journal of Plant \& Soil Science 4 (2): 156-170, 2015; Article no.IJPSS.2015.017 ISSN: 2320-7035.

[26] http://www.tropicos.org.

[27] Torres-Avilez, W., de Medeiros, P. M., \& Albuquerque, U. P. (2016). Effect of Gender on the Knowledge of Medicinal Plants: Systematic Review and Meta-Analysis. EvidenceBased Complementary and Alternative Medicine: eCAM, 2016, 6592363. http://doi.org/10.1155/2016/6592363.

[28] Marsha, B. Q. \& Robert, J. Q. (2007). Modernization and medicinal plant knowledge in a Caribbean horticultural village, medical anthropology quarterly, Vol 21 (2); 169-192.

[29] Jansen, P (1981). Spices, Condiments and Medicinal plants in Ethiopia, Their Taxonomy and Agricultural Significance. Centre for Agricultural Publishing and Documentation, Wageningen.

[30] Kaingu, C. K., Oduma, J. A. and Kanui, T. I. (2011). Practices of traditional birth attendants in Machakos District, Kenya. Journal of ethnopharmacology, 137 (1), 495-502.

[31] Nagata, J. M., Jew, A. R., Kimeu, J. M., Salmen, C. R., Bukusi, E. A. \&Cohen, C. R. (2011). Medical pluralism on Mfangano Island: use of medicinal plants among persons living with HIV/AIDS in Suba District, Kenya. Journal of ethnopharmacology, 135 (2), 501 - 509. 
[32] Maunguja A. B. (2016). Assessment of Plant Diversity and Utilization of Wild Medicinal Species by HouseholdsProximate to ArabukoSokoke Forest in Kilifi County of Kenya. Retrieved on 10/06/2018 from http://erepository.uonbi.ac.ke:8080/bitstream/handle/11295/97 469/Bakari_\%20Thesis.pdf?sequence=1\&isAllowed=y.

[33] Kisangau DP, Thora Martina Herrmann, Lyaruu HVM, Hosea KM, Joseph CC, Masimba ZH (2011). Traditional Knowledge, Use Practices and Conservation of Medicinal Plants for HIV/AIDS Care in Rural Tanzania. Ethnobot. J. 9:43-57.

[34] Owuor, B. O. and Kisangau, D. P. (2006). Kenyan medicinal plants used as antivenin: a comparison of plant usage. Journal of ethnobiology and ethno medicine, 2 (1), 1.

[35] Nanyigi, M. O., Mbaria, J. M., Lanyasunya, A. L., Wagate, C. G., Koros, K. B., Kaburia, H. F., Munenge, R. W. \& Ogara, W.
O. (2008). Ethno pharmacological survey of Samburu district, Kenya. Journal of Ethno biology and Ethno medicine, 4 (1), 1.

[36] Kimondo, J., Marion, J., Mutai, P. \& Njogu, P. (2015). Ethnobotanical survey of food and medicinal plants of the Ilkisonko Maasai community in Kenya. Retrieved on 18/10/2018 from https://www.sciencedirect.com/science/article/pii/S037887411 5301720?via\%3Dihub.

[37] Pacifica, B., Nyanchongi, B and Masai, R. (2018). Ethnobotanical Survey Of Medicinal Plants Used For Treatment Of Malaria By Kipsigis People In Kericho County, Kenya. IOSR Journal of Pharmacy and Biological Sciences (IOSR-JPBS) e-ISSN:2278-3008, p-ISSN:2319-7676. Volume 13, Issue 4 Ver. VI (Jul - Aug 2018), PP 24-30 www.iosrjournals.org. 